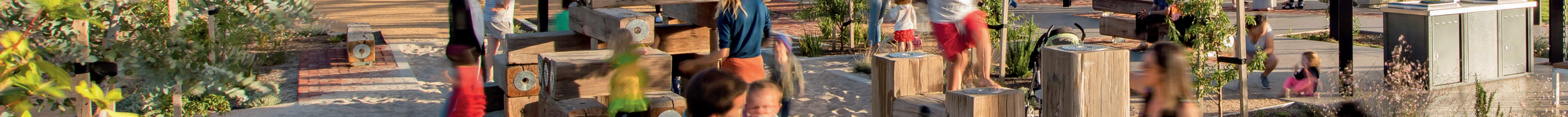

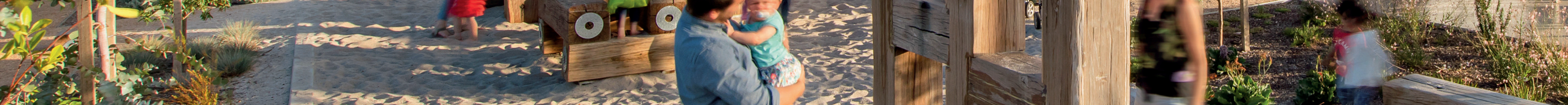

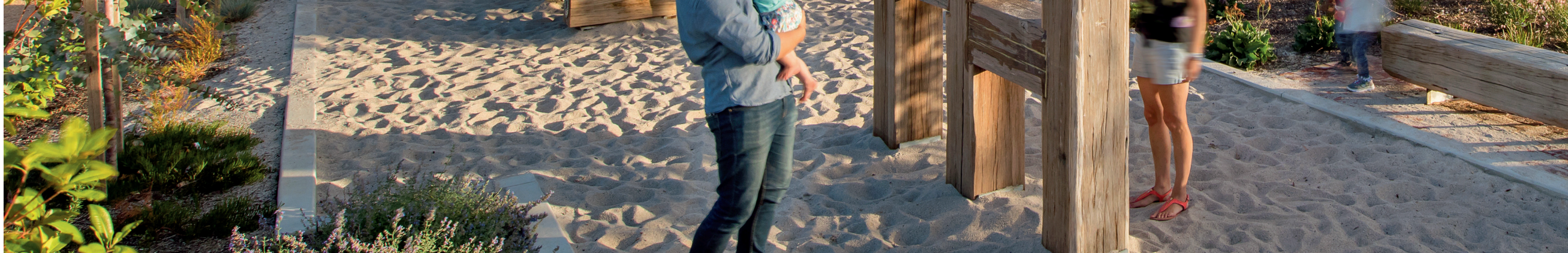
21)

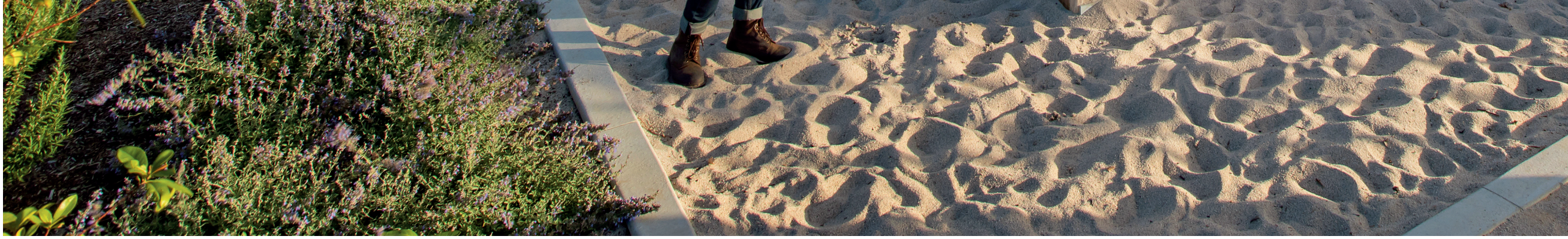




\section{澳大利亚阿德莱德市鲍顿主公园 BOWDEN MAIN PARK IN ADELAIDE, AUSTRALIA}

澳派景观设计工作室 / ASPECT Studios

引言

鲍顿改造项目是一个雄心勃勃的城市填 充式改造项目, 其将原先由奇胜电器公司占 据的 $15 \mathrm{hm}^{2}$ 的工业用地改造为一处集住宅、 零售、商铺于一体的新社区, 这个蓬勃发展 的社区可容纳约 3000 名居民。

\section{设计理念和策略}

南澳大利亚州政府发展机构一 南澳 城市更新组织负责推进该项目的全面总体规 划进程, 包括构建串联城市街道网络的休闲 场所、一处拥有不同居住密度的公寓式住宅 区, 以及一系列相互连接的公园。对阿德莱 德来说, 这是一种独有而先进的街道样式, 其通过采用共享街道的设计方式, 如引入平 埋路缘和雨水花园、广植树木等, 来确保行 人优先通行, 以最大限度地提升街道等公共 空间的品质。

在最初由T.C.L景观设计公司主导的总 体规划中, 公园被设想为新城区中的一个中 规中矩的广场。在尊重原总体规划方案的基 础上, 为实现公园在其所处城市环境中的功 能, 不仅需要设置诸如花园、休息区和林荫 草地等被动式景观空间, 还需要引入更多的 多功能空间, 如包括可用于大型活动的开放 草坪, 以及作为入口的步行廊道。步行廊道 连接起公园和零售区- -4 号工厂, 该建筑 已被重新改造为一处美食广场, 这里有小餐
https://doi.org/10.15302/J-LAF-20170509 收福时间 RECEIVED DATE / 2017-05-26 中图分类号 / TU986

文献标识的 / A
摘要

新建的鲍顿主公园坐落于南澳大利亚州鲍顿改造区中 心, 是当地最大的公共空间。它的建成大大推动了鲍顿地区在 阿德莱德中央商务区边缘地带创造一个多样化、有活力的新型 社区这一愿景的实现。鲍顿公园为占地 $15 \mathrm{hm}^{2}$ 的城市填充式 开发中心营造了一片绿洲, 这里将成为阿德莱德中心商各区外 国人最琱密的城市区域，预计将为学生、年轻家庭、首套房

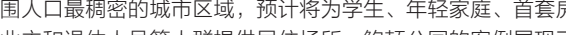
业主和退休人员等人群是供居住场和。鲍顿公园的案例展现了 一个思虑周全的设计如何建立人与人之间关系的纽带, 增强城 民提供适宜的场所。

关键词

可持续设计; 公共空间; 城市填充式改造; 社区参与

\section{ABSTRACT}

Bowden's new main park is the central and single largest public space located within the Bowden redevelopment in South Australia. It makes a significant step in realizing the vision for Bowden of creating a diverse and exciting new community on the edge of Adelaide's CBD. Bowden Main Park provides a green oasis in the heart of a 15-hectare urban infill development that will become Adelaide's most densely populated urban district outside the $C B D$, and an area projected to house a wide ranging demographic from students to young families, first home owners and retirees. Bowden Main Park is an example of how thoughtful and considered design can connect people, enhance the social and recreational fabric of the city and provide an authentic destination within the new and still establishing community. KEY WORDS

Community Engagement

整理 田乐

译 孙一鹤 田晓劼

EDITED BY TINa TIAN

TRANSLATED BY Robin SUN Xiaojie TIAN 


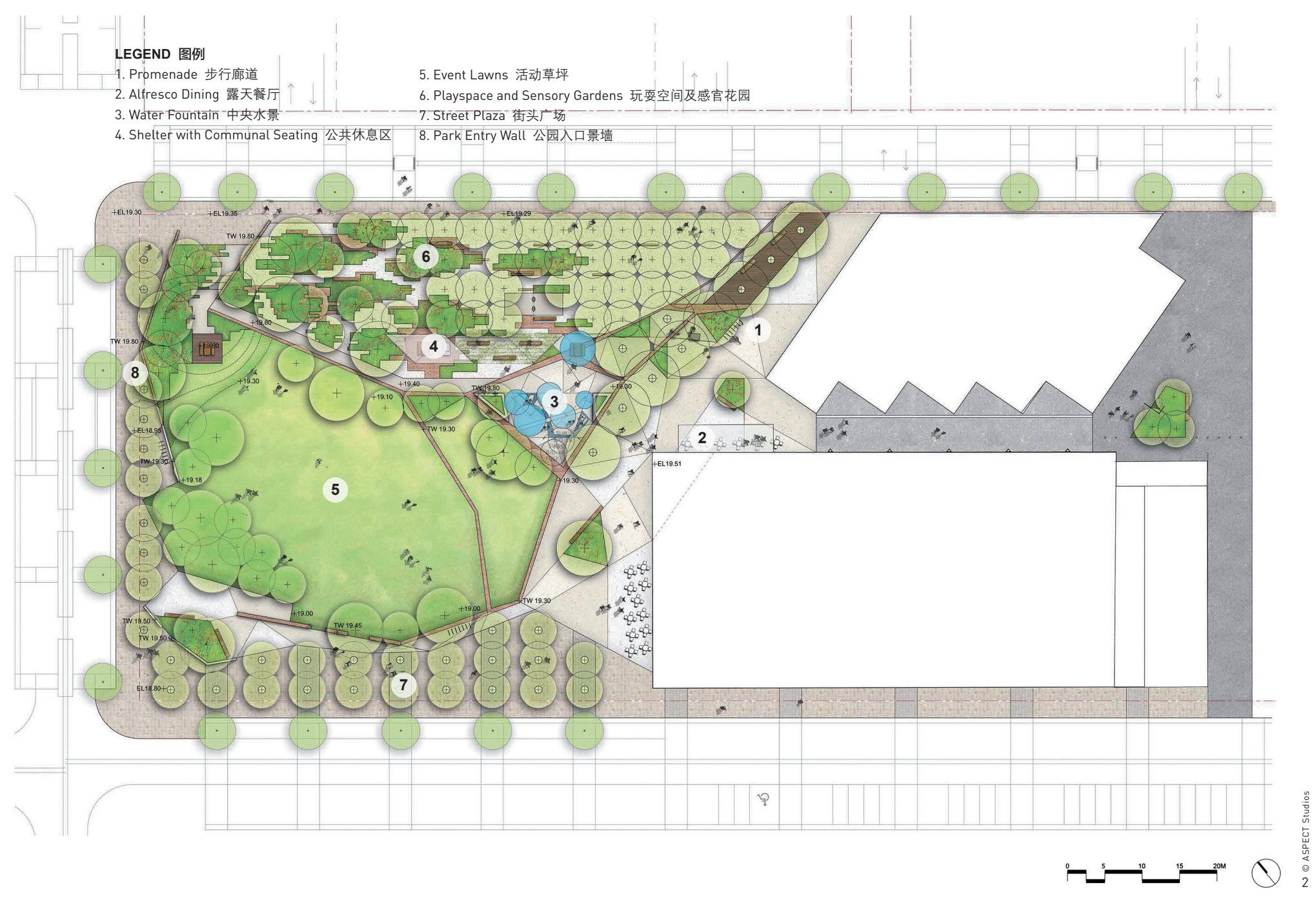

项目地址:

澳大利亚阿德莱德市鲍顿区

项目面积:

$5600 \mathrm{~m}^{2}$

项目委托：

南澳大利亚城市更新组织

景观设计:

澳派景观设计工作室

项目团队:

FMG工程设计公司（结构与水利工程）、Tonkin顾问公司 （市政与雨洪工程）、Lucid工程咨询公司（灯光与电气工

程）、澳大利亚景观工程服务公司（景观施工）

设计时间:

2014年5月 2015年9月

施工时间:

2015年12月 2016年8月

建成时间:

2016年9月
LOCATION:

Bowden, Adelaide, Australia

AREA (SIZE):

$5,600 \mathrm{~m}^{2}$

CLIENT:

Renewal SA

LANDSCAPE ARCHITECTURE:

ASPECT Studios

PROJECT TEAM:

FMG Engineering (Structural and Hydraulic Engineers),

Tonkin Consulting (Civil and Stormwater Engineers),

Lucid Consulting Engineers (Lighting and Electricat

Engineer), Landscape Construction Services (Landscape

Contractor)

DESIGN PERIOD:

May, 2014 September, 2015

CONSTRUCTION PERIOD:

December, 2015 August, 2016

COMPLETION TIME:

September, 2016
馆、每周市集、有机食品店和独立商店, 并 且定期举办活动。步行廊道作为一处重要的 纽带, 促进了公园和零售空间之间的互动 一通过廊道, 公共区域和商业区域真正紧 密地结合在了一起。

在该项目中, 澳派景观设计工作室致力 于为该区域提供一片城市绿洲和探索目的地 一一个与邻近的 4 号工厂美食广场、社区设 施及周边街道网络无缝衔接的独特的城市 公园。

为了满足人们的通行需求, 并吸引他们 驻足停留, 公园被设计为一个集休㮩、交际 和娱乐为一体的场所, 以及一处可供野餐、 烧烤和欣赏水景的聚集地。作为公园倾力打 
2. 鲍顿主公园总平面图

鲍顿主公园鸟瞰效果图

Master plan of Bowden

main park

3. Aerial view of Bowden main park
造的重点景观设施，一座喷泉被设置在路网 的节点处, 这是一个形式简单的旱喷设计, 在定制的遮阳结构下方, 呈星系状分布着 9 个喷嘴。水景四周还设有定制的座椅。人们 可伴着随机舞动的喷泉一同跳舞、嬉戏, 由 此，这片公园的中心地带成为了活力四射的 焦点。黄昏之后，LED灯通过各个喷嘴投射 出各色光线, 更为水景增添了一番趣味。

通过精心的设计，公园周边原来呆板的 街道网络被拆分成一条条充满趣味的小路, 吸引着游人从四面八方进入公园。由回收的 红砖铺设而成的路面具有棱角分明的裂纹肌 理, 让人联想起从前维多利亚时代工人居住 的屋舍, 这些小屋在奇胜公司的厂房建成之 前曾坐落在街道两旁。在公园的北缘, 零散 分布的植物和步道形成了一处迷宫, 围合起 一个独特的、完全由从码头回收的木材构成 的儿童游乐空间, 强化了公园设计期待提供 一处探索之地的愿景。

公园内材料和色调的选用参考了当地的 工业历史, “十” 形钢结构及应用在整个墙 面和路面铺装中的回收红砖均突显了工业美
学。钢结构和明亮色彩的运用重现了当年奇 胜电器公司的辉煌景象。两块哑光混凝土 铺路石以三角形图案排列, 犹如一块缝合场 地空间的“地毯”，吸引游客前来观赏中央 水景。

公园内随处可见的定制座椅为人们提供 了集会、倚靠、休䕀和冥想的场所。自行车 设施既为远道而来的游客提供了便利, 也促 进了鲍顿地区的可持续发展。此外，通过将 场地周边的花园与茂密的树木相结合, 不仅 实现了营造花园绿洲的愿景, 更有效地创造 出一种能够缓解周边区域城市热岛效应的微 气候。

对材料和场地几何形态的实验性运用不 仅是对这一区域工业历史的纪念，更表达出 了当代语境下鲍顿地区所具有的创造力和进 取性等核心价值观。公园提供了一个精心设 计的 “舞台”，鲍顿居民可以亲身参与塑造 这一不断变化的空间, 整个大阿德莱德地区 的人们都可以在这里寻找到全新的公共空间 体验一一这里有可供日常活动使用的开放草 坪, 众多可供聚餐聚会、艺术展示和玩要嬉

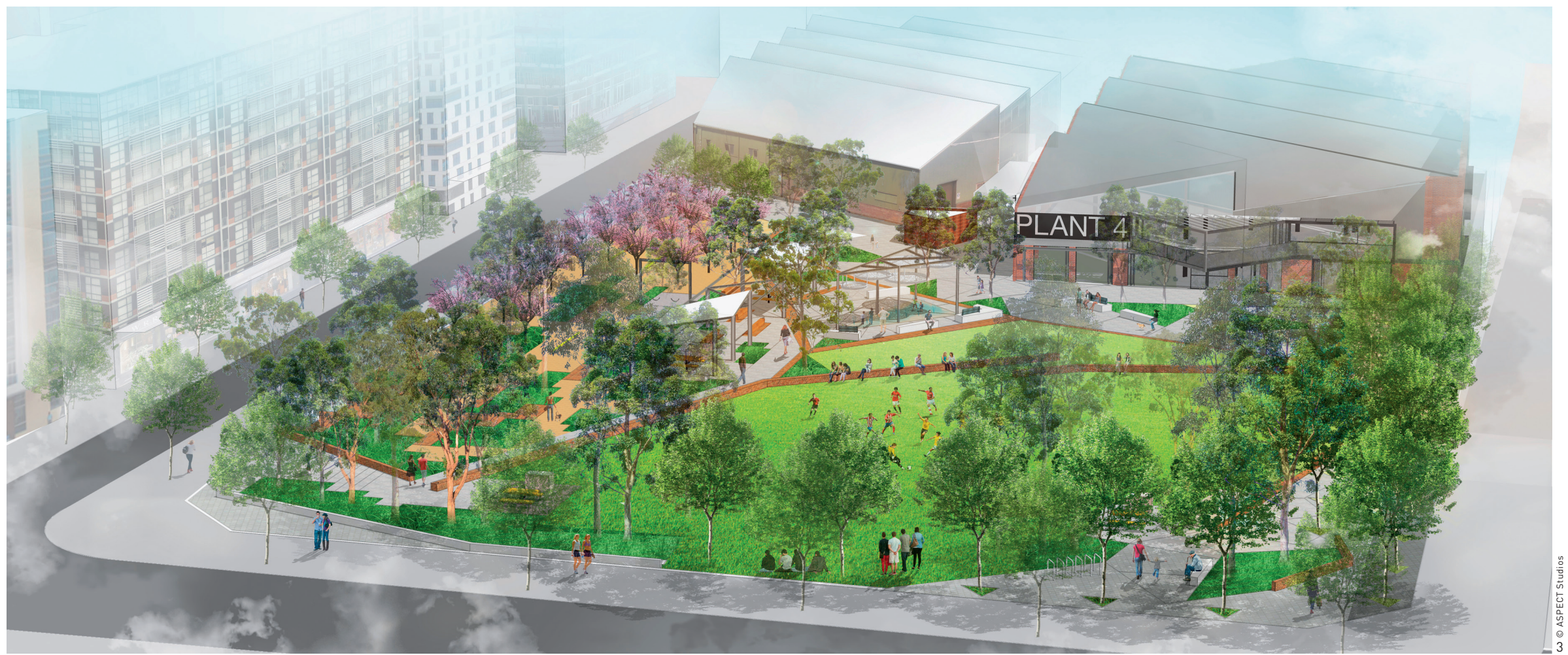




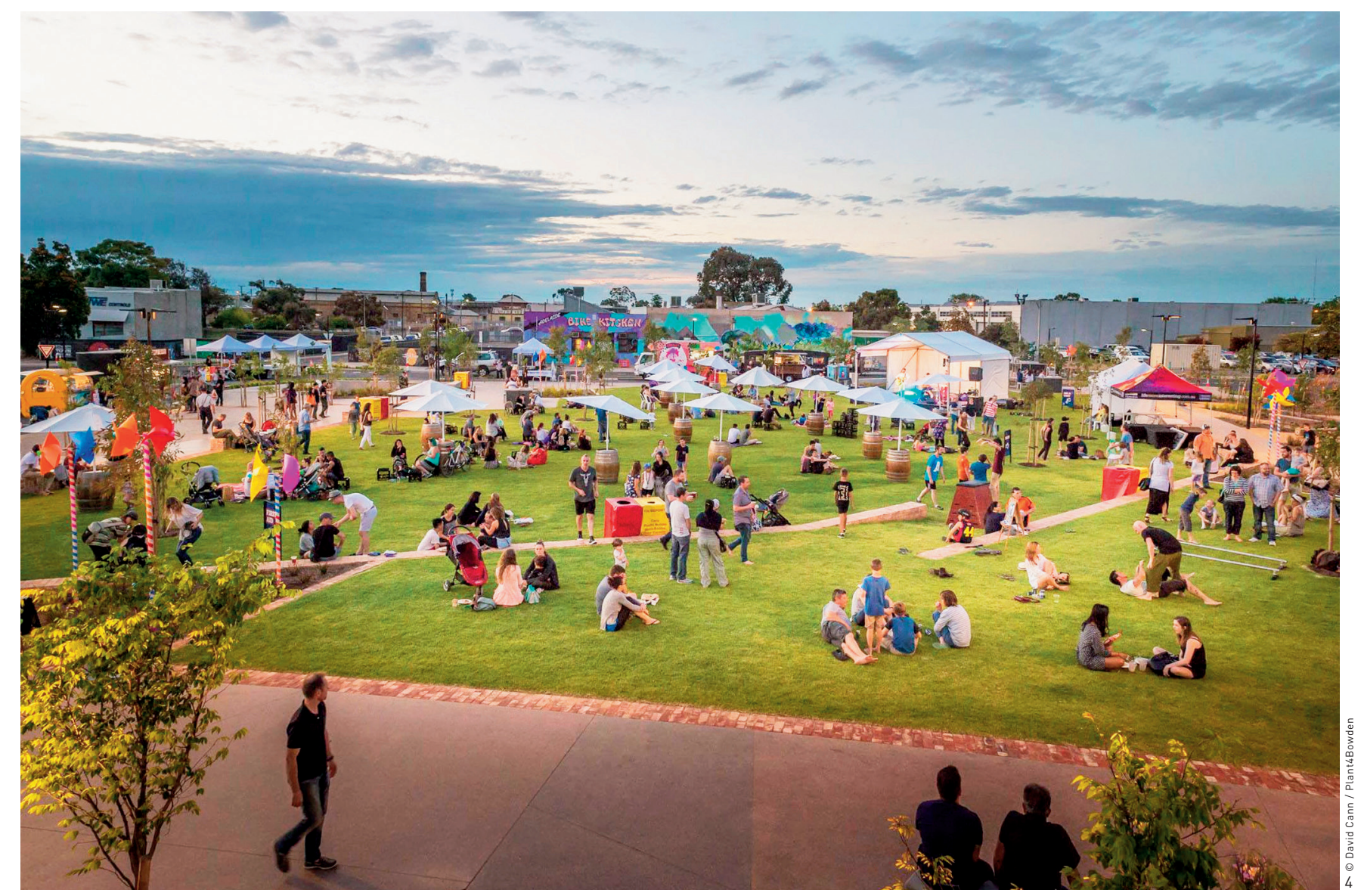

戏的设施。这个综合性的城市公园以其独 特的方式增强了社会凝聚力, 促进了人际 交往。

\section{合作和领导力}

该项目在建造阶段中曾暴露出一系列 问题, 这主要归因于 20 世纪初以来, 场地 内的工人屋舍被长期占用, 导致该地区不可 控的城市开发愈演愈烈。因此, 在整个建造 阶段, 设计方和施工方形成了紧密的合作关 系, 以评估建造方案的可行性。

项目落地过程以及别出心裁的场地布局 和土地混合利用策略的成功实践均突显了卓 越领导力的重要性。毗邻 4 号工厂大楼的鲍 顿主公园是阿德莱德独有的土地混合利用案 例, 它为人们带来了全新的公共空间体验。 在南澳城市更新组织鲍顿团队的领导下, 澳
派景观设计工作室把控着公园的设计方向。 通过与相关群体代表进行一系列设计研讨 会, 展现出了项目在探索突破性和试验性方 法过程中的优势。

\section{社区参与}

公园坐落于鲍顿改造项目的中心地带, 通过与州政府、地方政府及当地社区的长期 合作, 项目得以最终实现。在设计开发阶 段, 设计师定期与鲍顿社区相关团体举行会 议。通过听取当地社区的意见, 设计最大限 度地实现了居民的愿景, 创建了能够满足社 区需求的多功能趣味空间。尤其值得一提的 是, 为了满足居民提出的拥有聚集空间的需 求, 项目通过整合一大片中央草坪和起伏地 形, 在场地中的核心区域营造出了一处可供 居民开展各类活动的大型场所。
结语

随着鲍顿改造项目的顺利进行, 公园始 终秉持总体规划的目标: 在区域中心建造一 个活力四射的公共广场, 柔化周边棱角分明 的城市环境, 使之成为阿德莱德中心商务 区外围人口最稠密的城市地区中的花园绿 洲。得益于与之毗邻的 4 号工厂的成功运 作, 公园深受欢迎, 人们除了在 4 号工厂消 费之外, 也常在这里漫步、停留。尽管公 园周边还未被开发, 但从目前频繁的使用率 就能够预见其未来的升值空间。随着时间的 推移和人口的增长, 公园将进一步展现如何 通过周到、细致的设计连接人与人之间的关 系, 增强城市的社交和娱乐功能, 并在不断 发展的社区中营造一个真正适宜社区居民的 场所。LAF 
4. 鲍顿主公园成为阿德莱 德中心商务区外围人口 最稒密的城市区 花园绿洲。

5 中心草坪周边的花园为 场地带来了生机，同时 创造出一种能够缓解周 边区域城市热岛效应的 微气候。
4. Bowden main park offers a garden oasis which is to become one of the city's most densely populated densely populated urban districts outsid the CBD.

5. A fringe of gardens surrounding the central event lawns saturate the site with life, creating a responsive microclimate that mitigates the surrounding urban condition.

\section{Introduction}

The Bowden redevelopment is an ambitious urban infill project that has reclaimed 15 hectares of former industrial land, the old Clipsal electrical components company, transforming the site into a thriving new community of some 3,000 residents along with new retail and commercial premises.

\section{Design Concepts and Strategies}

Through an extensive master planning process undertaken by Renewal SA, the State Government development bureau, the project consists of the recreational area in a connected city street grid, an apartment mix from 3 up to 12 stories, and an interconnected series of parks. The street topography is unique and progressive for Adelaide, identifiable by a conscious design approach to prioritize pedestrian movement and maximize the quality of the street as an integral part of the public realm, by adopting shared street design principles such as flush kerbs, rain gardens and extensive tree plantings throughout.

The original master plan by Taylor Cullity Lethlean (T. C. L) identified the Park as a formal town square within a new urban precinct. Respectful of the master plan approach in terms of the function of the park within its urban setting, the programming for the park required a combination of passive landscaped spaces including gardens, seating areas and shady grassed spaces with trees and more multifunctional spaces including open grassed areas that can be

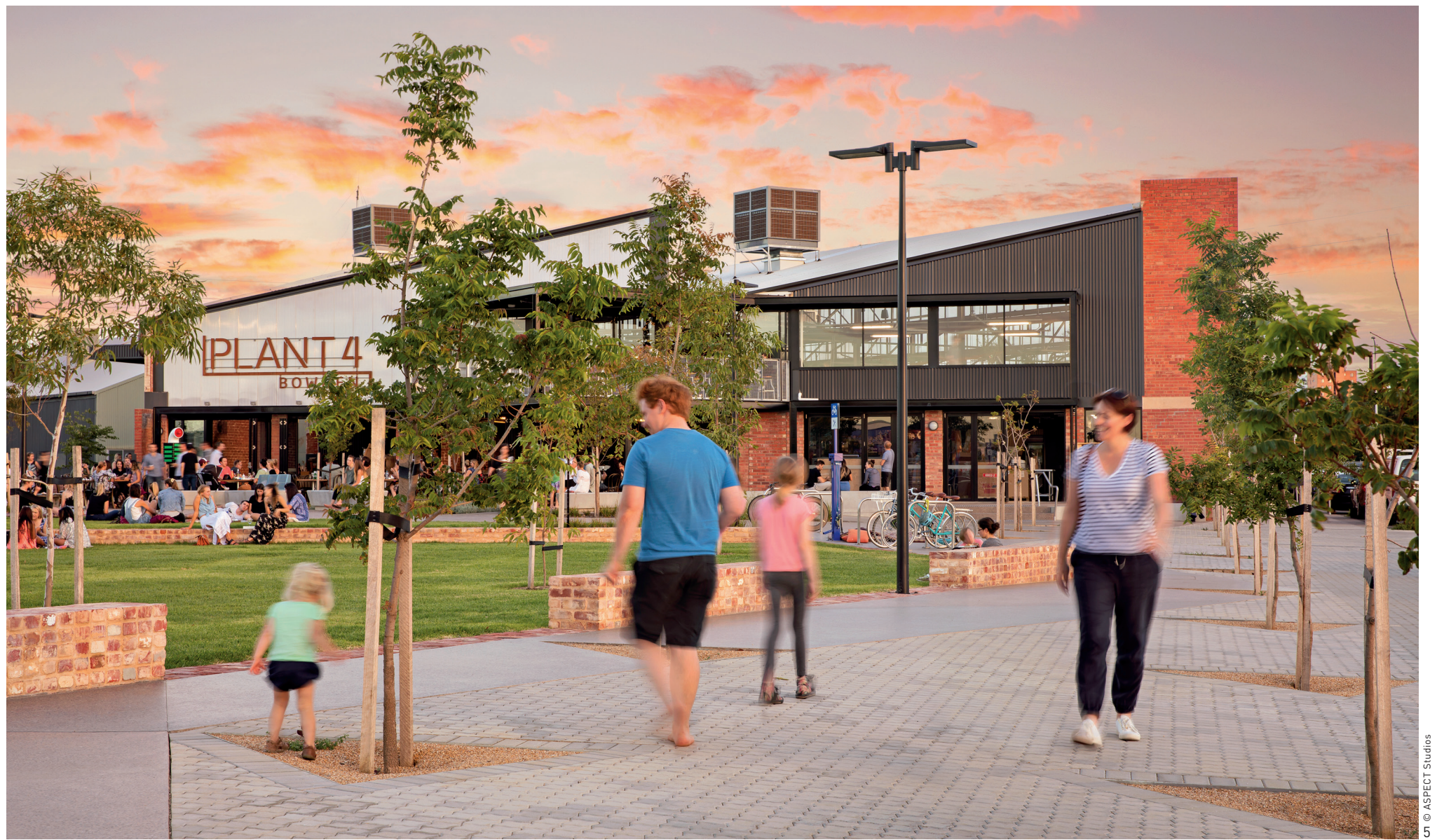




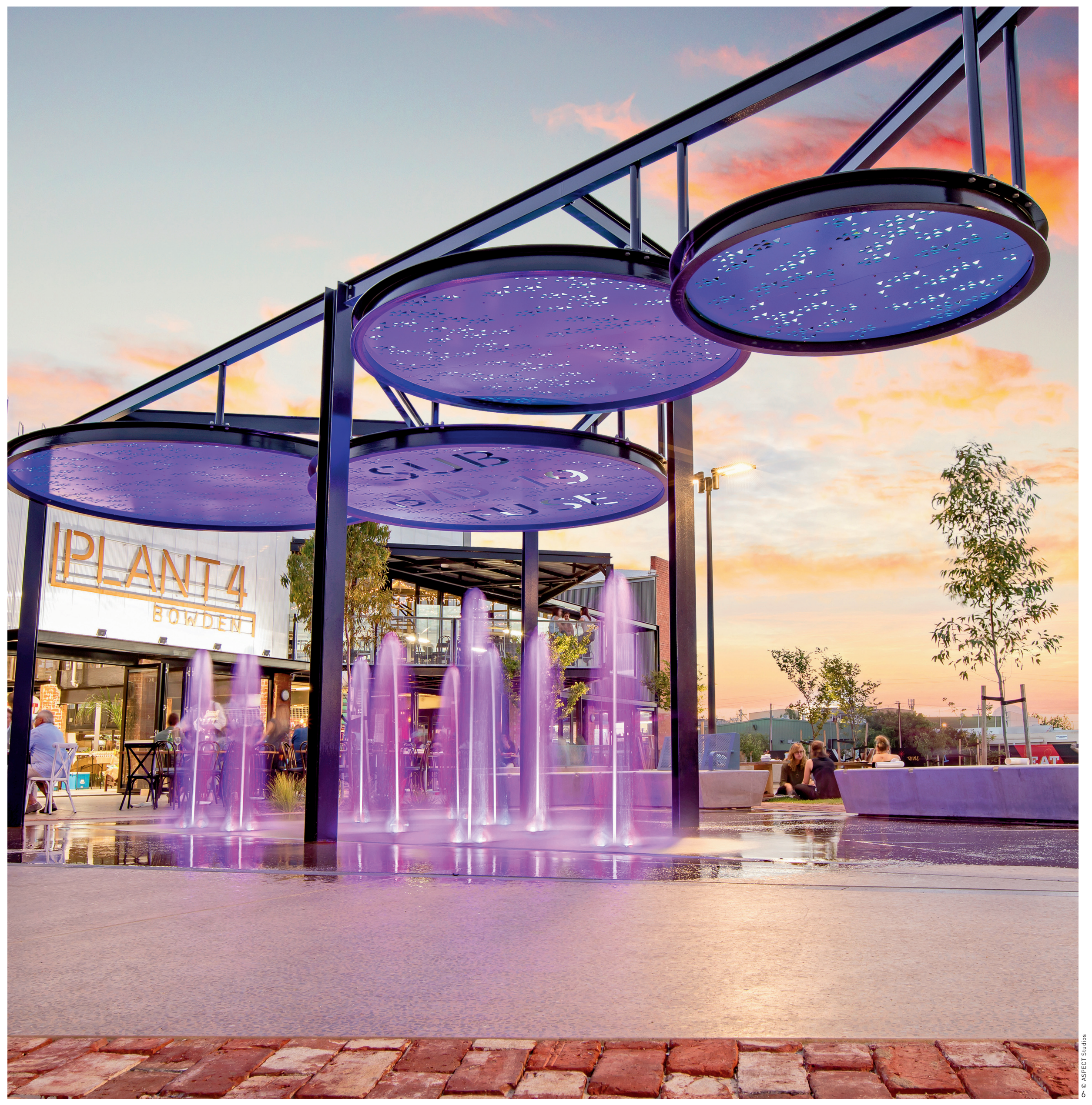


6. 中央水景将光线投射 到悬挂在上方的一系 列圆盘上

7 水景成为公园的中心 聚集区以及活力四射 的焦点。

8. 遮阳结构的细节呼应 了场地的历史。
6. The central water feature reflects light disks suspended above. as a central gathering space and point of focus.

8. Details of the shade structure reflect the site's history.

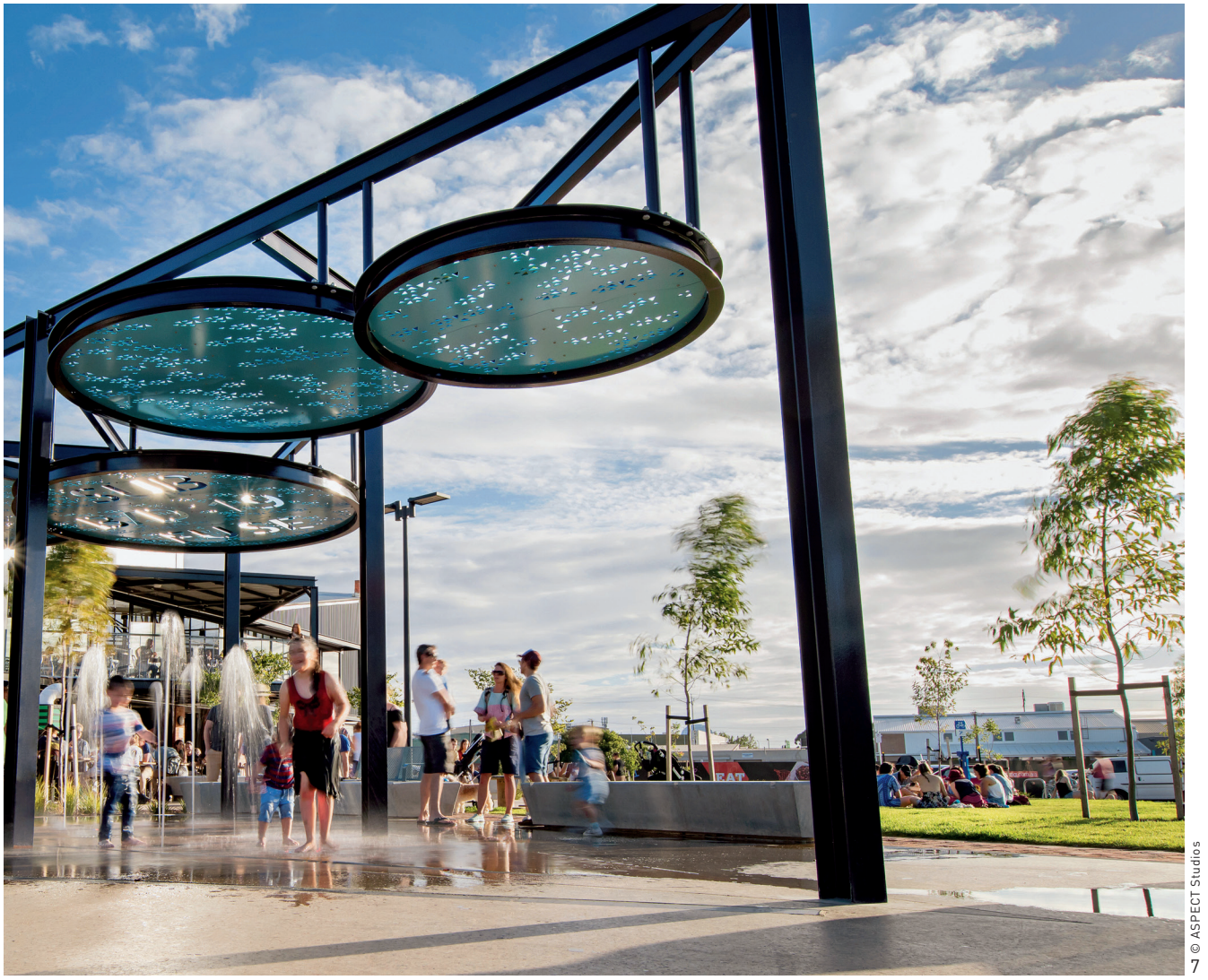

used for larger events and a pedestrian promenade that acts as a threshold. The promenade connects the park to the retail precinct - Plant 4, which has been repurposed as a foodie destination, with eateries, weekly produce markets, organic traders and indie stores, as well as regular events. The importance of this connecting strip cannot be understated. The interface between the Park and retail space is unique - a truly connected public realm and commercial precinct zipped together along the promenade.

ASPECT Studios' approach to the site focused on a desire to provide an oasis of green and a place of discovery - a unique urban park seamlessly integrated with the adjacent Plant 4 Food Markets and community facilities, as well as the surrounding street network.

Designed not only to draw people through, but also to attract them to linger. the Park has become a place of relaxation, social connection and recreation. A long shelter with picnic and barbeque areas and a field of water features act as a central gathering space. As a key investment in the Park, a water fountain is located at the nexus of the path network, designed as a simple splash pad with a series of 9 jets arranged in a stellar pattern under a bespoke shade structure. Surrounded by custom seats, the water feature is programmed for visitors to dance and play with a random pattern of fountains, creating an ever changing dynamic focal point and attraction in the heart of the park. LED lights project up through each jet, creating a beautiful patinae and further extending the attraction of the park as a destination beyond nightfall.

A deliberate design strategy was taken to deconstruct the formality of the surrounding street network by providing a fractal network 


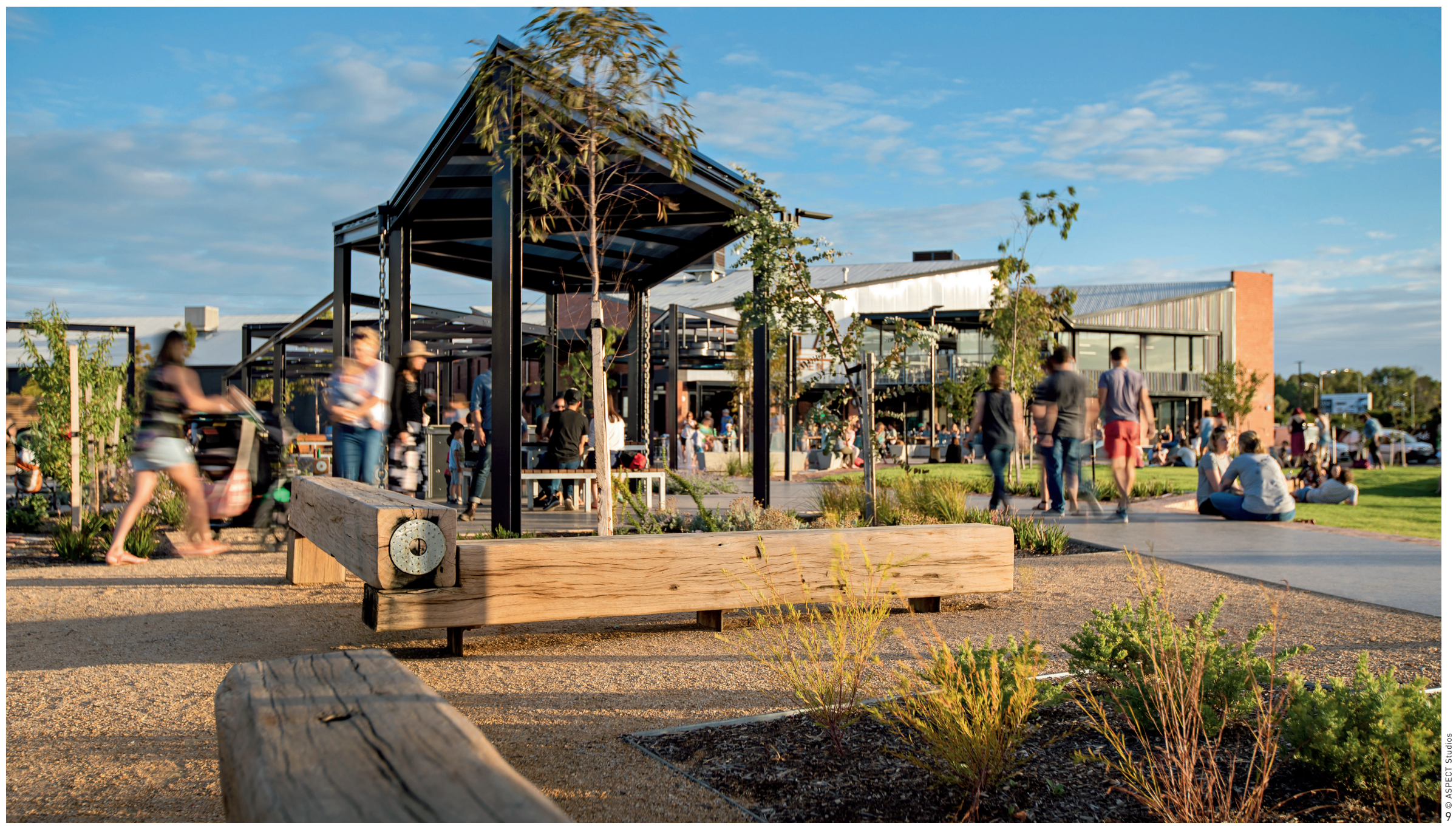

of pathways which invoke a sense of the playfulness, whimsy and delight, inviting people into the park from all directions. The angular geometry is reinforced by "cracks" in the pavement that reveal recycled red bricks, reminiscent of the former Victorian workers cottages which lined the streets prior to the site's occupation by the Clipsal factory. The notion of discovery continues via a labyrinth of scattered plants and pathways along the northern edge of the park, enclosing a unique children's play space constructed entirely of recycled jetty timbers.

The materials and tones reference the site's industrial past, informing an industrial aesthetic of steel " $T$ " beams for structures and the use of recycled red brick both as a wall finish and paving surface throughout. The use of steel and pops of color recall the days when the Clipsal electrical supply plants dominated the site. Two muted honed concrete paving stones laid in a triangulated pattern provide a carpet that stitches the site together, leading visitors to the central water feature.

Extensive informal and bespoke seating throughout the park provides numerous opportunities for gathering, leaning, resting and quiet contemplation. Bike facilities provide an additional utility for visitors from
9. 回收的红砖及码头木 材, 以及迷宫的设计强 化了设计一处探索之地 的愿景。

10. 材料和色调的选用参考 了当地的工业历史。

9. The overriding narrative of a place of discovery is reinforced through recycled red bricks, reclaimed jetty timbers and a labyrinth.

10. Details of materials and tones reference the site's industrial past. 
further afield and reinforce the Bowden sustainability initiatives. In addition, the concentration of gardens around the perimeter of the site in combination with a saturation of trees achieves the vision of a garden oasis, effectively creating a microclimate that tempers the urban heat island effects of the surrounding streets.

The experimental use of materials and site geometries not only is a nod to the site's heritage, but also consciously projects the site as a contemporary expression of the Bowden Village's core values of creativity and progressive thought. It provides a wellconceived canvas upon which the people of Bowden can mould into an ever changing space of their own making. What the people of Bowden and those from greater Adelaide can find here is a whole new public realm experience - a place with open lawns for informal play, with generous facilities for gathering, art, play, and delight; an integrated and distinct urban park that is centered on promoting social cohesion and interaction.

\section{Collaboration and Leadership}

Construction phase of the project presented its own series of issues, primarily due to the presence of uncontrolled fill as a result of many years of use across the site from workers cottages in the early 20th century. As a result, a close collaborative relationship between the design and construction teams was formed to assess solutions to constructability throughout the construction phase.

The project also demonstrates leadership through the process of delivery and its successful experimentation with unconventional site layout and land use mixes. The direct interface with the Plant 4 building is a unique land use mix for Adelaide and delivers an exciting new public realm experience. Under the leadership of Renewal SA's Bowden team, ASPECT Studios steered the direction of the park design, illustrating the benefits of a more unconventional and experimental approach to the site through a number of design workshops with the reference group members.

\section{Community Engagement}

Situated in the heart of the Bowden Redevelopment, the Park has been delivered through a long process of engagement between State and Local Government as well as the local Bowden community. Regular meetings were held with the Bowden Community Reference Group throughout the design development phase. By listening to the local community, the design delivers on their aspirations, providing a multifunctional and intriguing space that best fit for the community's needs. In particular, the need to create a usable gathering space was identified and helped shape a reconfiguration of the site with a large central lawn with mound forming a key part of the site.

\section{Summary}

With the Bowden development project well underway, this park delivers on the master plan objectives of creating a vibrant public square in the heart of the site, offering relief from its hard-edged urban surroundings; a garden oasis which is to become one of the city's most densely populated urban districts outside the CBD. Aided by the success of the adjacent Plant 4, the park is highly frequented and provides a place for visitors to linger beyond the shopping experience. Even prior to development occurring around the park, the intensity of use gives an insight into just how valuable this space will be. With time and an increased population imminent, the park will demonstrate how thoughtful and considered design can connect people, enhance the social and recreational fabric of the city, and provide an authentic destination within an establishing community. LAF
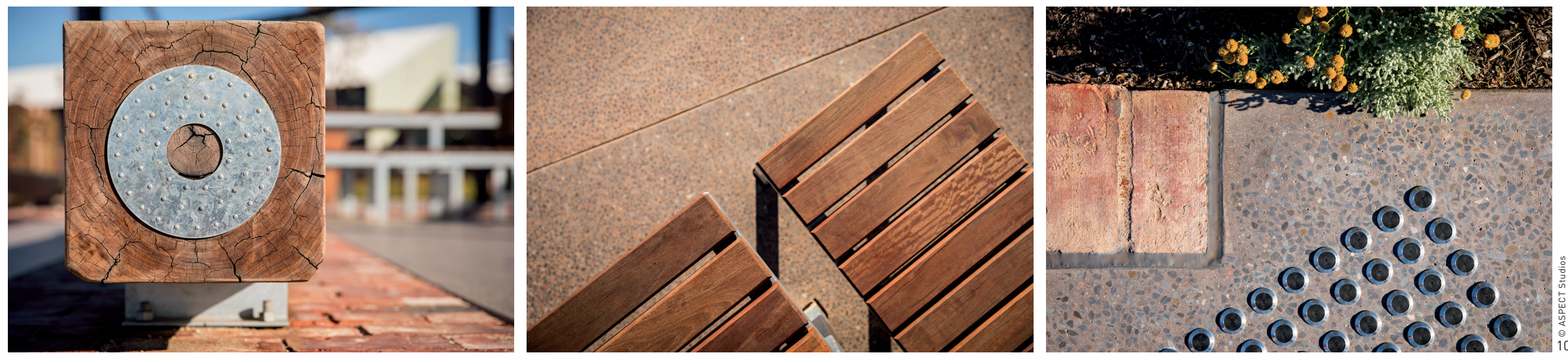